
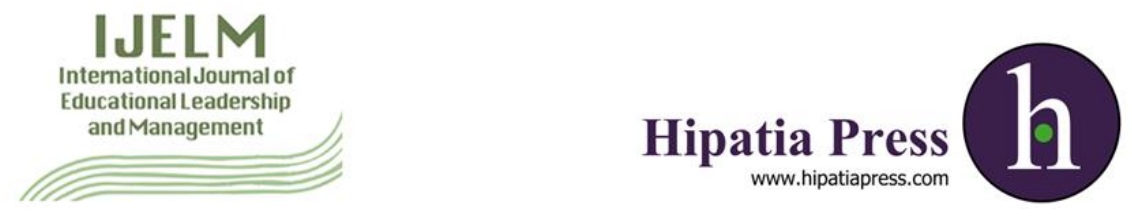

Instructions for authors, subscriptions and further details:

http://ijelm.hipatiapress.com

\title{
Campus Administrators' Responses to Donald Trump's Immigration Policy: Leadership during Times of Uncertainty
}

Jerry Burkett ${ }^{1}$

Sonya Hayes ${ }^{2}$

1) University of North Texas at Dallas. United States

2) University of Tennessee. United States

Date of publication: July $16^{\text {th }}, 2018$

Edition period: January 2018-July 2018

To cite this article: Burkett, J. \& Hayes, S. (2018). Campus Administrators' Responses to Donald Trump's Immigration Policy: Leadership during Times of Uncertainty. International Journal of Educational Leadership and Management, 6(2), 98-125. doi: 10.17583/ijelm.2018.3602

To link this article: http://dx.doi.org/10.17583/ijelm.2018.3602

PLEASE SCROLL DOWN FOR ARTICLE

The terms and conditions of use are related to the Open Journal System and to Creative Commons Attribution License (CCAL). 


\section{Campus Administrators' Responses to Donald Trump's Immigration Policy: Leadership during Times of Uncertainty}

Jerry Burkett

University of North Texas at Dallas
Sonya Hayes

University of Tennessee

\section{Abstract}

Donald J. Trump was elected the 45th President of the United States in November 2016, after more than a year of campaigning on many major issues. Among the key issues presented during then-candidate Trump's campaign was immigration reform. While Latinos make up the largest ethnic group of non-citizens in the U.S., most of these individuals have resided in the U.S. for a long period of time, have strong family ties, and have children who are lawful U.S. citizens (Baum, 2010; Almeida, Johnson, McNamara, \& Gupta, 2011; Sharpless, 2017). The Trump administration's early days involved a flurry of executive orders and other measures aimed at increasing the enforcement of immigration laws and blocking admission to the U.S. by individuals from specific countries. The purpose of this exploratory research study was to interview principals who lead Hispanic-majority elementary, middle, and high schools to determine how students and school communities are reacting to President Trump's current policy and rhetoric regarding immigration, and how these principals are responding to the students and communities they serve.

Keywords: Educational Leadership, Immigration, Principal

2018 Hipatia Press

ISSN: 2014-9018

DOI: $10.17583 /$ ijelm.2018.3602 


\section{Respuesta de los Administradores del Campus en relación a la Política de Inmigración de Donald Trump: Liderazgo en Tiempos de Incertidumbre}

Jerry Burkett

University of North Texas at Dallas
Sonya Hayes

University of Tennesse

\section{Resumen}

Donald J. Trump fue elegido el $45^{\circ}$ presidente de los Estados Unidos en noviembre de 2016, después de más de un año de campañas sobre muchos asuntos importantes. Entre los temas clave presentados durante la campaña del entonces candidato Trump estaba la reforma migratoria. Mientras que los latinos conforman el grupo étnico más grande de no-ciudadanos en los Estados Unidos, la mayoría de estos individuos han residido en los Estados Unidos por un largo período de tiempo, tienen fuertes lazos familiares y tienen hijos que son ciudadanos estadounidenses legales (Baum, 2010; Almeida, Johnson, McNamara y Gupta, 2011; Sharpless, 2017). Los primeros días de la administración Trump implicó una oleada de órdenes ejecutivas y otras medidas destinadas a aumentar la aplicación de las leyes de inmigración y el bloqueo de la admisión a los EE.UU. por parte de personas de países específicos. El propósito de este estudio de investigación exploratoria fue entrevistar a directores que dirigen escuelas primarias, intermedias y secundarias de mayoría hispana para determinar cómo los estudiantes y las comunidades escolares están reaccionando a la política y retórica actual del presidente Trump con respecto a la inmigración, y cómo estos directores están respondiendo al estudiantes y comunidades a las que sirven.

Palabras clave: Liderazgo educativo, inmigración, directores

2018 Hipatia Press

ISSN: 2014-9018

DOI: $10.17583 /$ ijelm.2018.3602
Hipatia Press

www.hipatiapress.com

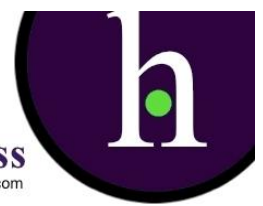




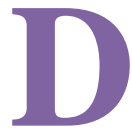

onald J. Trump was elected the 45th President of the United States in November 2016, after more than a year of campaigning on many major issues. Among the key issues presented during then-candidate Trump's campaign was immigration reform. "Of all of the candidates, Trump has been most vocal in his opposition to outsiders such as Muslims and illegal immigrants from Latin America and most openly critical of political correctness in both his rhetoric and his behavior" (Major, Blodorn, \& Blascovich., 2016, p. 8). However, despite broad rhetoric on immigration into the U.S., Trump's interest seemed largely focused on individuals migrating to the U.S. from Mexico. During his campaign for nomination in 2015, Trump accused unauthorized Mexicans of bringing drugs to the U.S., increasing crime, and calling these immigrants rapists (Rural Migration News, 2015; Martin, 2017a).

While Latinos make up the largest ethnic group of non-citizens in the U.S., most of these individuals have resided in the U.S. for a long period of time, have strong family ties, and have children who are lawful U.S. citizens (Baum, 2010; Almeida, Johnson, McNamara, \& Gupta, 2011; Sharpless, 2016). The Migration Policy Institute suggests there are approximately 820,000 noncitizens with criminal convictions that provide cause for removal (Sharpless, 2016, p. 255). Many of those individuals have recently committed youthful indiscretions, while some have decades-old convictions but have secured steady employment or a history of U.S. military service (Sharpless, 2016).

Trump's campaign rhetoric transcended into his presidential term, with continued accusations of Mexican illegal immigration exporting crime and poverty to the U.S., prompting promises to fulfill his campaign promise to build a wall along the US-Mexico border (Martin, 2017b). President Trump's focus on immigration has led to efforts to increase migration enforcement and the administration's announced intent to deport two to three million unauthorized immigrants (Sharpless, 2016; Chacon, 2017; Martin, 2017b). During his first two weeks in office, Trump issued executive orders calling for a ban on immigrants from Muslim-majority countries and denying U.S. entry for most refugees fleeing war-torn countries (Sharpless, 2016). Through the course of his presidency, Trump has continued to exercise his immigration policy by promising to rescind executive orders signed during the Obama 
102 Burkett, J. \& Hayes, S. - Campus Administrators' Reponses to Donald Trump's Immigration Policy: Leadership during the Times of Uncertainty

administration related to the Deferred Action for Childhood Arrivals (DACA) program (Martin, 2017b). DACA was designed to protect immigrant children who arrived illegally before the age of 16, are between ages 16 and 30, and have lived in the U.S. for a minimum of five years (Martin, 2017b, USCIS, 2012). Individuals meeting the DACA requirements would be eligible for work authorization and provided deferred prosecution for living in the U.S. illegally (USCIS, 2012).

Campaign promises from the president to "build the wall", coupled with hiring 15,000 additional Customs and Border Patrol and Immigration and Customs Enforcement agents, while publicly stating "We have some bad hombres and were going to get them out" have created a fear and uncertainty in the immigrant community (CNN, 2016, Sharpless, 2016). Markowitz (2017) of the Cardozo Law School noted: "I have never seen the level of panic that is gripping our immigrant communities" (Markowitz, 2017). This fear has had caused alarm in cities and states with large immigrant populations, and consequently, undocumented children have carried this fear into the public schools that serve them. Moreover, recent changes in political philosophy regarding immigration into the U.S. has led to protests and demonstrations in airports, schools, and public spaces across the country.

As researchers, we sought to understand how the Trump administration's views and rhetoric on undocumented immigration were impacting public schools in Texas. The purpose of our exploratory research study was to interview principals leading Hispanic-majority elementary, middle, and high schools to determine how students and the school community are reacting to the President's immigration policy and rhetoric, and how these campus leaders are responding to the students and communities they serve.

\section{Literature Review}

For the purpose of this literature review, we reviewed the literature available pertaining to Donald Trump's policy origins and the potential effects of the policies; the proposed "Travel Ban" from Muslim-majority countries; the proposed Border Wall and Border Security; the Deferred Action for 
Childhood Arrivals (DACA) program; and how educators have responded to undocumented immigrants in previous studies.

\section{President Trump's Policy Origins and Effects}

Unauthorized foreigners account for approximately $25 \%$ of the 44 million foreign-born residents in the U.S. (Martin, 2017b). The number of unauthorized foreigners rose rapidly between 1990 and 2007, peaking at 12 million in 2007. There was a sharp decline in immigrants during and following the economic recession of 2008 (Passel and Cohn 2016; Martin, 2017b).

Despite diminishing immigration levels, Donald Trump campaigned for president on an anti-immigration platform using deportation threats and "build-the-wall" chants to establish his policy on immigration reform. This rhetoric largely appealed to and garnered political support from uneducated White males. The findings from a Gallup survey between 2015 and 2016 revealed that Republicans who favored Trump were more likely than other Republicans to oppose free trade and immigration, more likely to be White, heterosexual, non-Hispanic males, and were less likely to have attained postsecondary education (Rothwell \& Diego-Rosell, 2016; Wilks, 2017). These individuals tend to view immigrants as people who come to the U.S. to steal prosperity (Wilks, 2017 p.296) because men without post-secondary education saw wages decrease from 1979 to 2013 (The Economist, 2015).

The Trump administration's early days involved a flurry of executive orders and other measures aimed at increasing the enforcement of immigration laws and blocking admission to the U.S. by individuals from specific countries. Hamann and Morgenson (2017) researched the effects of President Trump's rhetoric on small communities in Nebraska finding that as the investment in infrastructure construction continues "threats of deportations may not stop the undocumented from looking for and finding work, but it will divide parents from children" (p. 394) or force parents to send their children to live with other relatives. The authors predict that schools will close and that educators will lose jobs as immigrants disperse from their communities.

The authors argued that undocumented parents "will send their kids back to Mexico and Central America, scared about the prospect of their kids being 
104 Burkett, J. \& Hayes, S. - Campus Administrators' Reponses to Donald Trump's Immigration Policy: Leadership during the Times of Uncertainty

stranded and defenseless if they (the parents) get arrested (even as some of the hazards of living in many parts of Central America are well known)" (Hammaan \& Morgenson, 2017, p. 395).

\section{Travel Ban}

During Trump's first six months in office, his efforts turned to extreme vetting of immigrants from specific countries (Park, 2017). On January 27, 2017, Trump signed an executive order "which called for a temporary ban on admission to the United States by individuals from seven majority-Muslim countries" (Park, 2017, p. 185). President Trump cited the terrorist attacks of September 11, 2001 as a rationale for the ban, and asserted that "[d] eteriorating conditions in certain countries ... increase the likelihood that terrorists will use any means possible to enter the United States" (Executive Order 13769, 2017; Fullerton, 2017).

The Trump "Administration also proposed a ban on the admission of all Syrian refugees and a 120-day ban on the admission of all refugees, with the exception of individuals of minority religions in predominantly Muslim countries" (Chacon, 2017, p.257). Various states raised issue with the order, claiming religious discrimination against Muslims (Park, 2017, p.185). President Trump then issued a second executive order, which stated "it did not provide a basis for religious discrimination" and removed Iraq from the list of countries, "but the suspension remained for Iran, Libya, Somalia, Sudan, Syria, and Yemen” (Executive Order 13780, 2017; Park, 2017, p.185).

Negative consequences of Trump's travel ban includes separated families and decreased enrollment in U.S. colleges and universities by international students (Redden, 2017).

\section{Border Wall and Border Security}

On April 5, 2016 The Washington Post reported receiving a memo from then-Republican-nomination-candidate Donald Trump that outlined a strategy to force Mexico to pay for and build a wall along its border with the U.S. 
(Woodward \& Costa, 2015). The memo proposed threatening to cut off federal funding if Mexico did not make a payment of approximately $\$ 5$ to 10 billion to contribute to the cost of the wall. On January 25, 2017 President Trump signed Executive Order 13767, Border Security and Immigration Enforcement Improvements, which authorized the construction of a physical barrier along portions of the southern border of the U.S. (Executive Order 13767, 2017; Fullerton, 2017). The order also called for hiring additional Border Patrol agents. The Executive Order shifted federal funds to pay for the construction of a border wall, which Trump predicted would begin within months (Elliot and Miller, 2017) of his inauguration. Klingner (2017) suggests that many of the stated proposals from President Trump designed to improve border security are not new nor are they inexpensive. Under the Obama administration, the number of undocumented migrants arrested at the border or deported from U.S. actually increased. Since 2007, the flow of migrants from Mexico to the U.S. has been negative, as more individuals have left the U.S. than have arrived (Klingner, 2017).

\section{Deferred Action for Childhood Arrivals (DACA)}

Contrary to the Naturalization Law (1790), the most recent federal mandate governing immigrants is more considerate to children who arrived to the U.S. in an undocumented status prior to their 16th birthday. Under DACA, undocumented immigrants are granted temporary protection as they pursue legal immigration status. The purpose of DACA is to facilitate the process for undocumented youth to become full participating members of society. Under DACA, undocumented immigrant youth are able to enroll in school and seek employment while their immigration status is legalized.

Undocumented immigrants may request DACA if they meet the following criteria:

1. Were under the age of 31 as of June 15, 2012;

2. Arrived to the USA before reaching their 16th birthday;

3. Have continuously resided in the USA since June 15,2007 , up to the present time; 
106 Burkett, J. \& Hayes, S. - Campus Administrators' Reponses to Donald Trump's Immigration Policy: Leadership during the Times of Uncertainty

4. Were physically present in the USA on June 15,2012 , and at the time of making their request for consideration of deferred action with USCIS;

5. Had no lawful status on June 15, 2012;

6. Are currently in school, have graduated or obtained a certificate of completion from high school, have obtained a general education development (GED) certificate, or are an honorably discharged veteran of the Coast Guard or Armed Forces of the USA;

7. Have not been convicted of a felony, significant misdemeanor, or three or more other misdemeanors, and do not otherwise pose a threat to national security or public safety.

(US Citizenship and Immigration Services, 2016)

\section{Immigration and Customs Enforcement}

Along with Executive Order 13767 titled Border Security and Enhancements, President Donald Trump issued Executive Order 13768, Enhancing Public Safety in the Interior of the United States. The purpose of the order is to define executive policy to enforce immigration laws with specific emphasis on non-citizens who illegally enter the U.S. and those who overstay or violate the terms of their visas (Executive Order 13768). President Trump defined his policy through the Executive Order to ensure the U.S. uses all available resources to enforce the immigration laws of the country and to support the removal of non-citizens (Executive Order 13768).

With the additional funding for border troops and a change in executive policy to detain and remove undocumented residents, there was an increase in the numbers of arrests made by Immigration and Customs Enforcement (ICE), especially in the state of Texas. In 2017, three Texas cities ranked in the top 10 for ICE arrests (Dallas ranked first, Houston ranked third, and San Antonio ranked fifth) (Bialik, 2018). The city of Dallas had a $71 \%$ increase in the number of arrests compared to 2016 and was first in real numbers for 2017 with 16,520 arrests. (Bialik, 2018). 
Immigration raids have had a profound effect on children left behind after an undocumented individual was detained and deported from the U.S. Expansion of family detention exacerbates trauma in children, which has a direct impact on their health and development (Knopf, 2017). Many children left behind after immigration raids detained one or more parents experience secondary effects from deportation. This family fragmentation leads to extreme poverty and family dysfunction for those impacted (Rabin, 2018).

President Trump's policy intent in issuing Executive Orders was to support the removal of non-citizens, especially those who have committed violent crimes, as a way to protect communities. Trump also intended to provide support for American families who have been victims of crimes committed by aliens who were in the U.S. illegally (Executive Order 13768). Yet these enforcement policies have created nightmares throughout immigrant and noncitizen communities, as leaders continue to propagate that these enforcement policies actually strengthen national security (Aranda, Menjivar, \& Donato, 2014). For many families, the prospect of deportation has become a source of terror for children as well as for immigrant parents who fear they will be taken from their children (Dreby, 2010; Menjívar \& Abrego, 2012).

\section{Educators' Response to Immigrant Students}

Although Trump's rhetoric and immigration policies are recent developments, researchers and educators have been studying immigrant children and undocumented children in school settings for a number of years. Borjian and Padilla (2010) conducted a study on how American teachers can meet the needs of Mexican immigrant students and found that multicultural understanding, a strong learning environment, and knowledge of both English and Spanish languages were all factors that support the success of Mexican immigrant students in the classroom. Most notably, Borjian and Padilla asserted, "The educational success of immigrant students in the United States is highly dependent upon how we as a society view newcomers and their languages and cultures" (p. 325). They also added that immigrant children are successful when their "host society accepts and respects them" (p. 325). 
108 Burkett, J. \& Hayes, S. - Campus Administrators' Reponses to Donald Trump's Immigration Policy: Leadership during the Times of Uncertainty

Undocumented students have traditionally struggled with fears of deportation and access to a quality education (Gonzales, 2010). Gonzales (2010) found that educators who build strong relationships with unauthorized families can facilitate academic and social success in school for their undocumented students. Crawford and Valle (2016) studied school counselors and how these counselors encourage undocumented students' persistence in education. The authors found that counselors primarily were concerned with meeting their undocumented students' basic needs (e.g. safety, food, acceptance). Many of these counselors were focused on helping their students feel safe and accepted at school; establishing trusting relationships with their families, and ensuring the students completed the necessary forms to receive free breakfast and lunch. Crawford and Valle also stressed that more research was needed on school principals and how school leaders supported undocumented students (p. 20) because school leaders shape the culture, values, and climate of the school.

Crawford and Witherspoon-Arnold (2017) looked specifically at how "school leaders' talk and actions may create an ethos of reception and school climate for undocumented students" (p. 128). In their study they found that principals need to concentrate on building strong relationships with the parents of undocumented students and helping those parents understand the U.S. school system and how to help their children academically. They also found that many successful principals were effective communicators and relationship-builders who could create a school culture of inclusion and acceptance for all students and remove labels of "undocumented" and "immigrant" (p. 131). Furthermore, Crawford and Witherspoon-Arnold stressed the importance of principal the role in building culture and climate, as well as being intentional (p. 123) in creating an environment of acceptance for the success of undocumented students.

\section{Methodology}

The purpose of this exploratory research study was to interview principals who lead Hispanic-majority elementary, middle, and high schools to determine how students and school communities are reacting to President Trump's current policy and rhetoric regarding immigration, and how these 
principals are responding to the students and communities they serve. We used a snowball sampling technique where we reached out to one Hispanic principal of an elementary campus, Elisa, who works in a Hispanic-majority school in a University partner school district for hosting student teacher candidates. We asked Elisa if she would be willing to participate in the study and if she was aware of other colleagues who would also be interested. Elisa gave us the names of other colleagues, who then recommended more participants. All principals selected for the study serve in Texas schools where the Hispanic student population is measured at $75 \%$ or higher. The names, gender, and school level of the participants are outlined in Table 1.

\section{Participants}

Table 1

Interviewed Participants

\begin{tabular}{lll}
\hline Name & Gender & School Level \\
\hline Elisa & Female & Elementary \\
Loretta & Female & High School \\
Nina & Female & Elementary \\
Mario & Male & Middle School
\end{tabular}

The Research Questions that guided this study are:

1. How are Hispanic students and their parents responding to the President's current policy and rhetoric regarding immigration?

2. How are principals working in Hispanic-serving schools and their community members handling immigration concerns?

3. What lessons can be shared with other principals in how to handle student concerns regarding the President's immigration policy? 
110 Burkett, J. \& Hayes, S. - Campus Administrators' Reponses to Donald Trump's Immigration Policy: Leadership during the Times of Uncertainty

\section{Data Collection}

To understand how principals were responding to media coverage of President Trump's immigration and border wall policies and the impact of ICE raids in Texas, we adopted a qualitative, semi-structured interview technique that relied on personal interviews as the data collection method (Yin, 2011). Personal interviews are a particularly powerful method for "studying people's understanding of the meaning in their lived world" (Kvale, 1996, p. 105). Interviews can result in thick descriptions of the subject being studied (Lincoln \& Guba, 1985). We interviewed all participants and recorded their interviews using a digital recording device.

\section{Data Analysis}

We analyzed the data by reading and coding the transcripts of the interviews. Analysis consisted of open coding, a process whereby each sentence in the transcript was reviewed and assigned a meaning relative to the research question (Maxwell, 2013). Relationships between codes or clusters of codes suggested larger themes (Shank, 2002). Several themes emerged from the data, which are discussed in the findings.

\section{Findings}

The purpose of this exploratory research study was to interview principals who lead Hispanic-majority elementary, middle, and high schools to determine how students and the school community were reacting to the President's current policy and rhetoric regarding immigration, and how principals were responding to the students and communities they serve.

From the interview data, we determined that Trump's policies and rhetoric have created a culture of fear in schools that serve Hispanic students and their families; and consequently, principals are responding with empathy by maintaining strong relationships with their students and parents, advocating and supporting them, and stressing the importance of education. 


\section{Culture os Fear}

In this study, Trump's immigration policies and rhetoric corresponded to increased fear of deportation and fear of losing family members among undocumented families. Although, undocumented students have had a keen awareness of the possibility of being deported, the President's recent policies and rhetoric have intensified that awareness into a current reality of fear. All of the principals expressed that their parents and their students are living in fear since Trump's inauguration. Many Hispanic families are desperately afraid of ICE officers. Hispanic families are living in fear that they or a member of their family will be taken by ICE and sent to a detention facility or deported from the U.S. Parents are also afraid that ICE will pick up their children from school and deport them. Because of this fear, many children are not attending school and are not allowed to leave their parents' side. One of the elementary principals, Elisa, explained:

"The parents are afraid - afraid to go out to even bring the kids to school, and that's the fear that is driving them not to bring kids to school or not to go anywhere. That affects the kids because kids want to go play and go to school, and the parents hesitate now because they hear how people are being picked up and taken. They are afraid to bring their kids to school worried their kids will be picked up [by immigration] and who will pick up their kids if they [parents] are picked up by immigration - scared of not knowing what is going to happen to their family."

Many of the families have experienced ICE coming to their homes and taking family members away. Because of this experience, the parents' fear is palpable. Mario expressed that he has had "about five or six students who have had either a direct mother or father or a family member - I'm talking about aunt, uncle, cousin - who have already been deported because of this. One of them just lost his father. His father was deported. He's afraid to go home because he doesn't know if his mom or uncle or cousins will be there".

Adding to this fear is the lack of understanding of the English language and immigration policies. Mario explained that "almost $80 \%$ of them [parents] do not speak English," and Nina added that "some of our parents are refugees, and they don't understand the current policies or the language." 
112 Burkett, J. \& Hayes, S. - Campus Administrators' Reponses to Donald Trump's Immigration Policy: Leadership during the Times of Uncertainty

Nina and Mario also iterated that because their parents do not speak the language, they are getting their information from other Hispanic families, and this is adding to the fear because they do not always have the correct information.

The participants reported that the students, especially older students, are afraid as well. High school students have told their principal that "the President just wants to get rid of them." The older students have the same fears as their parents in regards to ICE and deportation. Loretta, a high school principal explained:

"Right after Donald Trump was elected, I was wondering if they are concerned. And, sure enough, when I got here [school] I started seeing how they were feeling. They were scared - very scared; didn't want to come to school, and they had so many questions for me. They were very afraidafraid their parents were gonna be deported and that they would be split from their parent. One student said she was afraid that when she got home her parents weren't gonna be home, and that they were gonna be gone. She was definitely afraid of the minutes ticking by, she just thought any minute now they're gonna go get my family, and I 'm gonna go home to nothing. "

Nina also asserted that "the kids are scared - especially the older kids because they're more aware of their parents' status. They have come to school crying and they are stressed - worried about whether they're going to find their parents at home when they get out of classes." All of the participants discussed the stress and fear their students are experiencing. Many of their students are legal citizens, but their parents are not, and the children come to school worried that they will never see their parents again if they are deported. The principals discussed how their students are withdrawn and/or crying in school, and they are having a difficult time focusing on academics. They also discussed that many students are absent from school because of the fear of deportation and their schools' attendance rates have declined. Nina also explained that many parents have just picked up and left, and the students are not seen again. 


\section{Importance of Relationships}

Responding to the fear in which many of their families are living, the principals discussed the importance of relationships. The principals expressed that forming positive relationships with all of their families has allowed them to be able to respond more to their needs. One way to build relationships with non-English speaking families is to ensure that bilingual staff are available in the schools. Elisa explained, "I think having someone who is a Hispanic staff member, who speaks Spanish, and who is skilled at developing very nurturing and warm relationships with families make them feel comfortable enough to be honest and share their fears and talk about what they need, so then the school can respond - that's a huge piece."

The principals also discussed the importance of communication in parent relationships, especially reassuring parents that their child is safe. Nina explained:

"Communication has been key to reinforcing our relationships with parents - spending time with them one-on-one and talking to them. I've spent quite a bit of time building relationships with parents so they will come to me to have one-on-one conversations - it is safer that way instead of trying to bring everyone together. It is important to reassure parents - be confident and assure that you [the principal] will make sure their child is okay - tell them your plan for an emergency; help them understand their child is safe at school."

Other principals also discussed the importance of communication and talking with parents and students to address their fears. Mario stated:

"It might not be popular, but the key is to talk to all these things. You need to talk to students. You need to have parent community town hall meetings. Those things all took time for me. They took time away from student's classes and took time away from my social life. I pulled students in groups of one to 20. It took me two days to talk to all the students. So, it was two days away from a principal's schedule. It was a lot. That was worth it to me. I got more out of that than anything else I could have done because if I wouldn't have done that, if I would have just maybe spoke to all of them at 
114 Burkett, J. \& Hayes, S. - Campus Administrators' Reponses to Donald Trump's Immigration Policy: Leadership during the Times of Uncertainty

once, my message wouldn't have been there. My message wouldn't have been as possible if I had a large group and I could not look at their faces. They needed to see my face when I told them with all my heart nothing is going to happen."

All of the principals asserted that they were regularly telling students and parents that their children were safe at school.

Principals also explained that part of communicating with parents and students was also showing empathy for what they were experiencing. They expressed that they did a lot of listening and supporting. Loretta explained, "I need to stop and think about how others feel and how it impacts them because it doesn't personally impact me or my family members. I have to take a step and be more empathetic about it - take the time to find the right words and hope I don't mess up...to be compassionate." One of the principals showed empathy by sharing his own story of immigrating to the U.S. as a child. Mario explained:

"My parents immigrated here from the Dominican Republic, and when we first moved here, we were in poverty - I have a lot of passion for students coming from other countries trying to get an education and the struggles they have. I have experienced what my students are experiencing like the fear of learning a new language - fear of living in a new country, living in poverty - I just try to help and empathize with them; relate to them, you know. But, just letting them know that no matter how scared they feel, we understand. We're listening to them. We 're empathetic."

The principals also expressed how their empathy and compassion extends to their teachers and helping teachers support their students. Elisa explained that she has been supporting her teachers who have strong relationships with immigrant families and who are able to have conversations with them to provide support and information. Mario also explained working with teachers has been critical because many of the teachers do not understand how the immigration policies have been affecting their students and some of his teachers have told him that this issue has been a distraction from students' learning. Mario explained that he has had to have crucial conversations with 
teachers and remind them that "they can't think about instruction until they get with dealing with the safety result. It is very hard to teach a student who doesn't feel safe and just feels anxious and fearful." The elementary school principals also expressed that many of their teachers have been playing a maternal role to their students, and as their principals they have had to find ways to support these teachers of immigrant students and the additional emotional strain it has placed on them. Elisa shared, "We're talking a whole lot right now [with teachers] about trauma influence classrooms - really trying to figure out how to educate kids and provide their social and emotional support that our kids need because they've experienced horrific things already at four-year-olds." All of the principals expressed that they have worked with their teachers to support them in and out of the classroom to help create a safe place for their students to continue to learn. Part of this work included a review of Maslow's hierarchy of needs and reminders to abstain from discussing politics and the teachers' own political views with students.

\section{Support and Advocacy}

All of the principals we interviewed were passionate about helping and supporting their families in any way possible. The principals stressed the importance of advocating for their students and families and providing them with resources to help them. Many of the principals hosted family information nights, which included immigration lawyers and social workers in attendance to offer legal advice and support. Loretta, one of the high school principals, explained:

"We are working through our feeder pattern to support our families help them find resources, legal aid, and counseling. We are trying to bring awareness by offering support on how to find an attorney or counseling services. We also found community resources and got agencies to come to an event at school - help parents fill out paperwork for citizenship and for a Social Security card."

Mario, a middle school principal, also hosted a family night and stated, "I planned a town hall meeting and I planned a couple of parent conferences to try to reach as many families as possible. And I feel that really worked for me." He also met personally with all of his students to reassure them that they 
116 Burkett, J. \& Hayes, S. - Campus Administrators' Reponses to Donald Trump's Immigration Policy: Leadership during the Times of Uncertainty

are safe on campus. He told both parents and students that "I would lose my job before letting any student get taken away, and I'm here to keep you safe." Reassuring kids and parents and that they are safe and advocating for them by finding resources and support in the community was a common sentiment expressed by all the principals.

Other principals also found resources and support for their families and made sure that parents had access to these resources. As leaders of these campuses, the principals felt very strongly about advocating and supporting their students and families. Nina explained:

"We have contacted social workers and counselors to offer support. The social workers has some legal contacts that our families can get assistance from. We have done a lot of reassurance to both kids and parents. The Parent Involvement Center has provided a list of immigration lawyers that will help consult for free. We constantly reassure our parents on how we treat our children - we love on them and treat them as if they are our own. If a day comes and they can't pick up their child, then we will do everything in our power to get them with family - we are making sure emergency contacts are updated and we have good contacts for other people even if they are in another state so we can find family members."

The principals expressed the importance of building community partnerships to provide resources to families and communicating with families through family nights, personal home visits, small groups, and one-on-one.

\section{Importance of Education}

Some of the principals expressed that their students' education was suffering, and they had seen a drop in school attendance and grades. Nina expressed, "We've seen a drop in grades with our 5th graders. They are having a hard time focusing especially in our bilingual classes - the grades are dropping because they are unable to focus. We've had $20 \%$ of our students absent on designated walk-out or stay at home days; over 1/2 of our bilingual students are absent more frequently." The principals are addressing these 
concerns by stressing the importance of education and their passion for helping all students find success.

Because of this passion, the principals have focused on trying to keep the business of school as normal as possible for their students. Nina stated:

"Our primary focus as a school is to stay the course - education opens opportunities and we need to stay the course and keep pushing for student achievement, especially in ES, we're dealing with the basics - reading, writing, arithmetic, and we have to continue to move forward because we need to make sure we give our kids a strong foundation because regardless of what may or may not happen, these are life skills that we are teaching them.'

Mario expressed that he grew up in poverty, and "my dad always gave us a speech that education was the way out - he lived it - went to night school to get his degree, his Master's and eventually his PhD and he became a professor. He inspired me, and I try to instill that love of education for others - especially my students." He also expressed that although he tries to keep a normal routine at school, he and his staff do not ignore the realities of the current environment. He has trained his staff on how to answer the students' questions when they have them and not to ignore their reality. He has encouraged his teachers to find ways to bring their current reality into their lessons and to create relevancy for their students. Loretta expressed the same sentiment when she stated, "Our history classes are pulling some of the current events, political events into lessons and making it relevant to what is happening today and how it affects immigration and people." By using the current political climate and the reality in which their students are living, the principals are creating meaning for their students and reinforcing to them that they matter, their reality matters, and they care. Alicia, disturbed by Trump's policies and rhetoric expressed that they have to combat the hate and bigotry through education. She stated, "All of this perpetuates bigotry and hate and all of the things we fight so hard every day. We want to create a whole different world through our kids - we teach tolerance and love for everybody no matter what color they are religion they are, or whatever." It is through advocacy, support, love, and dedication to their students that these principals are combating the political implications of Trump's immigration policies. 
118 Burkett, J. \& Hayes, S. - Campus Administrators' Reponses to Donald Trump's Immigration Policy: Leadership during the Times of Uncertainty

Education is the key to their students' success, and the principals are continuously fighting for their students' education.

\section{Discussion}

At the very basic level of creating a positive learning culture for a school, the principal is responsible for ensuring a safe learning environment. Most principals generally address common school safety concerns such as bullying, horse-playing, fire and bad weather drills, and even student nourishment. However, many principals are not accustomed to having to assuage fears held by parents and students of being detained by ICE officers and deported from the country. Principals, who serve in schools with high numbers of Hispanic students that may or may not be undocumented, have found themselves handling an unprecedented level of fear and trauma within their school community. How the principals in this study have responded to their students and parents living in this fear should be emulated by other principals in similar situations. We believe that by learning from these principals' actions, other school leaders will have the necessary tools to advocate and support immigrant students in this uncertain time.

It is not uncommon for principals to advocate for the students on their campus. Many assume the role of an advocate in the course of bearing much of the responsibility and accountability for the achievement of their students and faculty. However, the principals interviewed in this study assumed the role of an advocate above and beyond their role as principal or instructional leader. As many of these principals share common factors with their students (i.e., first-generation immigrant, Hispanic heritage, or growing up in an impoverished home), they assume the role of an empathetic and compassionate leader that goes beyond traditional advocacy roles. The principals interviewed in the study appear to use their understanding of law, education, and community support systems to effectively communicate to their parents and students not only how to navigate complicated rhetoric and fear, but how to advocate for themselves if necessary.

We argue that these principals assume these roles not out of obligation to their students and parents, but rather through a self-realized responsibility 
to advocate for the members of their school community as leaders of their respective schools. The principals interviewed in this study exhibit high qualities of educational leadership traits through their effective use of communication, their relational capacity with their community, and their ability to mobilize resources inside and outside of the school district to calm the fears generated by President Trump's rhetoric and his executed policies. In effect, these practices demonstrate that these principals understand the necessity to remove internal and external barriers that may ultimately hinder the academic success of their students.

\section{Conclusion}

President Donald Trump's rhetoric on immigration created a culture of fear among members of the Latino/x community across the U.S. The fears were driven through execution of Executive Orders largely aimed at deportation of non-citizens, sustained rhetoric on building a border wall between the U.S. and Mexico and banning immigrants from selected countries from coming to the U.S. These policies have had a direct effect on students in Hispanic-majority schools. As students and parents rely on the school community for support and information, principals have answered the call by extending their normal roles as instructional leader into a larger role that appears to advocate for the student beyond concerns for academic success. Although campus leaders are trained to assume the role of building manager, supervisor, and instructional leader when they take the role of principal, individuals that participated in this study have demonstrated another level of leadership that is not captured from a typical graduate degree program. It is apparent that, given the circumstances that have caused intense concern for members of their school community, principals are willing to exercise resources and employ methods to advocate on behalf of their students to ensure their access to education and achieve academic success.

\section{References}

Almeida, J., Johnson, R. M., McNamara, M., \& Gupta, J. (2011). Peer violence perpetration among urban adolescents: Dispelling the 
120 Burkett, J. \& Hayes, S. - Campus Administrators' Reponses to Donald

Trump's Immigration Policy: Leadership during the Times of Uncertainty

myth of the violent immigrant. Journal of Interpersonal Violence, 26(13), 2658-2680.

Aranda, E., Menjívar, C., \& Donato, K. M. (2014). The spillover consequences of an enforcement-first U.S. immigration regime. American Behavioral Scientist, 58(13), 1687-1695.

Baum, J., Jones, R., \& Berry, C. (2010). In the child's best interest?: The Consequences of losing a lawful immigrant parent to deportation. Collingdale, PA: Diane Publishing.

Bialik, K. (2018). ICE arrests went up in 2017, with biggest increases in

Florida, northern Texas, Oklahoma. Pew Research Center.

Retrieved from http://www.pewresearch.org/facttank/2018/02/08/ice-arrests-went-up-in-2017-with-biggestincreases-in-florida-northern-texas-oklahoma/.

Berkeley, J. (2015, May 30). The weaker sex. The Economist. Retrieved from http://www.economist.com/.

Borjian, A., \& Padilla, A.M. (2010). Voices from Mexico: How American teachers can meet the needs of Mexican immigrant students. Urban Review, 42(4), 316-328.

Chacon, J. M. (2017). Immigration and the Bully Pulpit. Harvard Law Review Forum, 130(7), 243-268.

CNN Video. (2016). Donald Trump: We need to get out 'bad hombres' -

CNN Video. (October 19, 2016). Retrieved from https://www.cnn.com/videos/politics/2016/10/19/thirdpresidential-debate-trump-immigration-bad-hombres-sot.cnn

Crawford, E.R., \& Valle, F. (2016). Educational justice for undocumented students: How school counselors encourage student persistence in schools. Education Policy Analysis Archives, 24(98), 1-28. Crawford, E.R, \& Witherspoon Arnold, N. (2017). We don't talk about undocumented status...we talk about helping children: How school leaders shape school climate for undocumented immigrants. 
International Journal of Educational Leadership and Management, 5(2),116-147.

Dreby, J. (2010). The burden of deportation on children in Mexican immigrant families. Journal of Marriage and the Family, 74(4), 829-45.

Elliott, P., \& Miller, Z. J. (2017). How President Trump is trampling precedent. Time, 189(4), 9.

Executive Order 13767 (25 January 2017). Retrieved from

https://libproxy.library.unt.edu:2246/the-press-office/

2017/01/25/executive-order-border-security-and-immigrationenforcement-improvements

Executive Order 13768 (27 January 2017). Retrieved from

https://www.whitehouse.gov/presidential-actions/executive-orderenhancing-public-safety-interior-united-states/

Executive Order 13769 (27 January 2017). Retrieved from

https://libproxy.library.unt.edu:2246/the-press-office/ 2017/01/27/executive-order-protecting-nation-foreign-terroristentry-united-states

Executive Order 13780 (March 16, 2017). Retrieved from

https://www.whitehouse.gov/presidential-actions/executive-orderprotecting-nation-foreign-terrorist-entry-united-states-2/

Fullerton, M. (2017). Trump, turmoil, and terrorism: The US immigration and refugee ban. International Journal of Refugee Law, 29(2), 327338.

Gonzales, R.G. (2010). On the wrong side of the tracks: Understanding the effects of school structures and social capital in the educational pursuits of undocumented immigrant students. Peabody Journal of Education, 85(4), 469-485.

Hamann, E. T. \& Morgenson, C. (2017). Dispatches from flyover country: Four 
122 Burkett, J. \& Hayes, S. - Campus Administrators' Reponses to Donald

Trump's Immigration Policy: Leadership during the Times of Uncertainty

appraisals of impacts of Trump's immigration policy on families, schools, and communities. Anthropology \& Education Quarterly, 48(1), 393-402.

Klingner, D. (2017) Trump against the world: His policies toward Mexico, and the resistance from inside and outside the United States, Public Integrity, 20(1), 1-8.

Knopf, A. (2017). Immigrant families across America facing 'black cloud' of stress and deportation. Brown University Child \& Adolescent Behavior Letter, 331-2.

Kvale, S. (1996). Interviews: An Introduction to Qualitative Research Interviewing. London: Sage.

Lincoln, Y. S., \& Guba, E. G. (1985). Naturalistic inquiry. Newbury Park, CA: Sage.

Major, B., Blodorn, A., \& Blascovich, G. M. (2016). The threat of increasing diversity: Why many White Americans support Trump in the 2016 presidential election. Group Processes \& Intergroup Relations.

Markowitz, P. (February 2017). Understanding What Makes Trump's Immigration Orders Truly Chilling, N.Y. Daily News. Retrieved from http://www.nydailynews.com/opinion/trump-chillingimmigration-orders-article-1.29817

Martin, P. (2017a). Election of Donald Trump and migration. Migration Letters, 14(1), 161-171.

Martin, P. (2017b). Trump and U.S. immigration policy. California Agriculture, 71(1), 15-17.

Maxwell, J. (2013). Qualitative Reserarch Design: An Interactive Approach. Thousand Oaks, CA: Sage Publishing.

Menjívar, C., \& Abrego, L. J. (2012). Legal violence: Immigration law and the lives of Central American immigrants. American Journal of Sociology, 117(5), 1380-1421. 
Park, L. D. (2017). Immigration: Bigger budget, more enforcement, travel ban battles. Labor Law Journal, 68(3), 184-186.

Passel J.S \& Cohn D. (2016). Overall number of U.S. unauthorized immigrants holds steady since 2009. Pew Research Center. Retrieved from www.pewhispanic.org/2016/09/20/overallnumberof-u-s-unauthorized-immigrants-holds-steady-since-2009/.

Rabin, N. (2018). Understanding secondary immigration enforcement:

Immigrant youth and family separation in a border county. Journal of Law \& Education, 47(1), 1-39.

Redden, E. (30 January 2017). Donald Trump travel ban hits scholars and students. Inside Higher Ed. Retrieved from https://www.timeshighereducation.com/news/donald-trump-travelban-hits-scholars-and-students\#survey-answer

Rothwell, J. \& Diego-Rosell, P. (2016). Explaining nationalist political views: The case of Donald Trump, Unpublished Manuscript. Retrieved from https://papers.ssrn.com/sol3/papers.cfm?abstract $\mathrm{id}=2822059 \& \mathrm{rec}$ $=1 \&$ srcabs $=2355164 \&$ alg $=1 \&$ pos $=4$

Rural Migration News (2015). DAPA, Politics. Volume 21, Number 4. Retrieved from https://migration.ucdavis.edu/rmn/more.php?id=1925.

Shank, G. (2002). Qualitative research: A personal skills approach. Upper Saddle River, NJ: Merrill Prentice Hall.

Sharpless, R. (2016). Immigrants are not criminals: Respectability, immigration reform, and hyperincarceration. Houston Law Review, 53(3), 691-764.

US Citizenship and Immigration Services (USCIS). (2012). Consideration of Deferred Action for Childhood Arrivals (DACA). Retrieved from https://www.uscis.gov/archive/consideration-deferred-actionchildhood-arrivals-daca

US Citizenship and Immigration Services. (2016). Consideration of deferred action for childhood arrivals. Retrieved from 
124 Burkett, J. \& Hayes, S. - Campus Administrators' Reponses to Donald

Trump's Immigration Policy: Leadership during the Times of Uncertainty

\section{www.uscis.gov/humanitarian/consideration-deferred-action- childhoodarrivals-daca}

Wilks, S. (2017). A complicated alchemy: Theorizing identity politics and the politicization of migrant remittances under Donald Trump's presidency. Cornell International Law Journal, 50(2), 285-305.

Woodward, B. \& Costa, R. (5 April 2015). Trump reveals how he would force Mexico to pay for border wall, Washington Post. Retrieved from https://www.washingtonpost.com/politics/trump-wouldseek-to-block-money-transfers-to-force-mexico-to-fund-borderwall/201 6/04/05/c0196314-fa7c-1 Ie5-80e4c381214dela3_story.html.

Yin, R.K. (2011). Case study research design and methods. Thousand Oaks, CA: Sage. 
Dr. Jerry R. Burkett is the Assistant Dean of the Emerging Teacher Institute at the University of North Texas at Dallas. He has more than 17 years of experience as an educator, serving as a teacher, campus and district-level administrator, and professor. He received his doctorate in educational leadership from Dallas Baptist University with specialization in alternative and traditional certification and its relationship to classroom management. He earned a Master of Education degree from Dallas Baptist University and his Bachelor of Science in Education from Baylor University.

Serving as a passionate advocate for public education, Dr. Burkett writes and speaks on a variety of topics, including school finance, instructional technology, brain learning, and the needs of public education in the 21 st century. He has spoken at national, state, and regional conferences, various university doctoral cohorts, and community and civic groups.

Dr. Burkett was featured in the 2014 documentary, The Texas Promise, a documentary about challenges facing the Texas public education system. He was named as a 2013 Phi Delta Kappa Emerging Leader and the 2013 Dallas Baptist University Alumni of the Year.

Contact Address: University Hills Blvd Dallas, Texas, 7300.

E-mail: jerry.burkett@untdallas.edu

Dr. Sonya Hayes is Assistant Professor Educational Leadership at University of Tennesse. Dr. Hayes graduated with her PhD in Educational Administration from Texas A\&M University in College Station. She holds a M.Ed. in Educational Administration, and a BA in English. Her research interests include principal preparation, urban education leadership, and a principal's influence on teacher efficacy and equity and excellence in education. Specifically, she is interested in how principals improve teaching and learning for all students and how universities are preparing principals for instructional leadership. She served in public education as a high school English teacher, a high school assistant principal, and a middle school principal for 23 years prior to coming to LSU. She is an active member in the University Council for Educational Administration and serves as the Associate Editor for the Learning and Teaching newsletter.

Contact Address: Baton Rouge, Louisiana 70803.

E-mail: sonyahayes@1su.edu 